\title{
Density and diversity of macroinvertebrates in Colombian Andean streams impacted by mining, agriculture and cattle production
}

\author{
Ana María Meza-Salazar ${ }^{1,2}$, Giovany Guevara ${ }^{3}$, Lucimar Gomes-Dias $^{1}$, Carlos A. Cultid-Medina ${ }^{\text {Corresp. } 4,5}$ \\ ${ }^{1}$ Facultad de Ciencias Exactas y Naturales, Grupo de Investigación BIONAT, Universidad de Caldas, Manizales, Caldas, Colombia \\ 2 Department of Applied Ecology, North Carolina State University, College of Agriculture and Life Sciences, North Carolina, North Carolina, United States \\ 3 Facultad de Ciencias, Departamento de Biología, Grupo de Investigación en Zoología (GIZ), Universidad del Tolima, Ibagué, Tolima, Colombia \\ 4 Red de Diversidad Biológica del Occidente Mexicano, Instituto de Ecología, INECOL A.C., Pátzcuaro, Michoacán, México \\ 5 CONACYT, Ciudad de México, Ciudad de México, México \\ Corresponding Author: Carlos A. Cultid-Medina \\ Email address: carlos.cultid@inecol.mx
}

Background. Mining, agriculture and cattle production are activities that threaten the quality and quantity of water resources in the Colombian Andes. However, many drainage basins in this region have not been subjected to simultaneous evaluation of the impact these activities have on the density, diversity and composition of aquatic macroinvertebrates (AMI). The first two of these ecological variables are expected to decrease drastically from zones with no apparent impact towards areas with anthropogenic activity, which areas with mining will present the most impoverished AMI community.

Methods. We evaluated the density, diversity and composition dissimilarity of AMI in streams impacted by gold mining, agriculture and cattle production. Two reference streams were also studied. Six benthic samplings were conducted bimonthly (Feb 2014 - Feb 2015) using a Surber net. Water samples were taken in order to make environmental evaluation among the aforementioned streams, including hydrological, physicochemical and bacteriological parameters (HPCB). Diversity was evaluated as the effective number of RTUs - recognizable taxonomic units - by comparing the richness, typical diversity, and effective number of the most abundant RTUs. Compositional dissimilarity was examined with nMDS and CCA analysis.

Results. 7483 organisms were collected: 14 orders, 42 families and 71 RTUs. Our prediction regarding the density and diversity of AMI (Reference > Cattle production > Agriculture > Mining) was partially fulfilled, since the agriculture-dominated stream presented a more impoverished AMI community than that of the gold mining stream. However, these streams presented lower diversity than the cattle production and reference streams, and the AMI density only differed significantly between one reference stream and the agriculture stream. The AMI composition in the agriculture-dominated stream clearly differed from that of the other streams.

Discussion. The observation of a more impoverished AMI community in agricultural production areas compared to those with mining or cattle production may reflect the importance of the remaining riparian vegetation, which was scarce at the stream with agricultural activity. Moreover, the low diversity, and mainly the reduced AMI richness, in the agriculture stream coincided with the absence of insect genera are intolerant to deterioration of the biological and physicochemical conditions of the water (e.g. Anacroneuria). 
Conclusions. The results suggest that the local impact of agricultural activities may be of equal or greater magnitude than that of mining in terms of AMI density, diversity and composition, in the Colombian Andean riverscape. Future studies should systematically evaluate, throughout the annual cycle, the relative effects of the productive land use, the remaining native vegetation cover and the consequent changes in the HPCB parameters of the water on AMI communities in Colombian Andean basins. 
1 Diversity and density of macroinvertebrates in Colombian Andean streams impacted by

2 mining, agriculture and cattle production

3

4 Ana María Meza-Salazar ${ }^{1,2}$, Giovany Guevara ${ }^{3}$, Lucimar Gomes-Dias ${ }^{1}$, Carlos A. Cultid-

5 Medina $^{4,5^{*}}$

6

7

$8{ }^{1}$ Facultad de Ciencias Exactas y Naturales, Grupo de Investigación BIONAT, Universidad de

9 Caldas, Manizales, Colombia

$10{ }^{2}$ College of Agriculture and Life Sciences, Department of Applied Ecology, North Carolina

11 State University, North Carolina, United States

$12{ }^{3}$ Departamento de Biología, Facultad de Ciencias, Grupo de Investigación en Zoología (GIZ),

13 Universidad del Tolima, Ibagué, Colombia

$14{ }^{4}$ CONACyT, Ciudad de México, México.

$15{ }^{5}$ Red de Diversidad Biológica del Occidente Mexicano, Instituto de Ecología, A.C., Pátzcuaro,

16 Michoacán, México.

20 Corresponding author:

21 Carlos A. Cultid-Medina.

22 Av. Lázaro Cárdenas No. 253, Col. Centro, 61600 Pátzcuaro, Michoacán, México.

23 Email address: carlos.cultid@,inecol.mx 


\section{Abstract}

25 Background. Mining, agriculture and cattle production are activities that threaten the quality and quantity of water resources in the Colombian Andes. However, many drainage basins in this region have not been subjected to simultaneous evaluation of the impact these activities have on the density, diversity and composition of aquatic macroinvertebrates (AMI). The first two of these ecological variables are expected to decrease drastically from zones with no apparent impact towards areas with anthropogenic activity, which areas with mining will present the most impoverished AMI community.

32 Methods. We evaluated the density, diversity and composition dissimilarity of AMI in streams impacted by gold mining, agriculture and cattle production. Two reference streams were also studied. Six benthic samplings were conducted bimonthly (Feb 2014 - Feb 2015) using a Surber net. Water samples were taken in order to make environmental evaluation among the aforementioned streams, including hydrological, physicochemical and bacteriological parameters (HPCB). Diversity was evaluated as the effective number of RTUs - recognizable taxonomic units - by comparing the richness, typical diversity, and effective number of the most abundant RTUs. Compositional dissimilarity was examined with nMDS and CCA analysis.

Results. 7483 organisms were collected: 14 orders, 42 families and 71 RTUs. Our prediction regarding the density and diversity of AMI (Reference $>$ Cattle production $>$ Agriculture $>$ Mining) was partially fulfilled, since the agriculture-dominated stream presented a more impoverished AMI community than that of the gold mining stream. However, these streams presented lower diversity than the cattle production and reference streams, and the AMI density only differed significantly between one reference stream and the agriculture stream. The AMI composition in the agriculture-dominated stream clearly differed from that of the other streams. 
47 Discussion. The observation of a more impoverished AMI community in agricultural production

48 areas compared to those with mining or cattle production may reflect the importance of the

49 remaining riparian vegetation, which was scarce at the stream with agricultural activity.

50 Moreover, the low diversity, and mainly the reduced AMI richness, in the agriculture stream

51 coincided with the absence of insect genera are intolerant to deterioration of the biological and

52 physicochemical conditions of the water (e.g. Anacroneuria).

53 Conclusions. The results suggest that the local impact of agricultural activities may be of equal

54 or greater magnitude than that of mining in terms of AMI density, diversity and composition, in

55 the Colombian Andean riverscape. Future studies should systematically evaluate, throughout the

56 annual cycle, the relative effects of the productive land use, the remaining native vegetation

57 cover and the consequent changes in the HPCB parameters of the water on AMI communities in

58 Colombian Andean basins.

Keywords: Aquatic insects, Hill series, Biomonitoring, Rank-Density curve, Neotropical region.

61

62 Introduction

63 Over the last four decades, pressure on lotic systems has increased in an accelerated manner at

64 global level as a consequence of the rapid expansion of areas of anthropogenic exploitation

65 (Haddeland et al., 2014). The main threats to global freshwater diversity include

66 overexploitation, water pollution, flow modification, habitat destruction/degradation and

67 invasion by exotic species (Dudgeon et al., 2006; Vörösmarty et al., 2010; Malaj et al., 2014;

68 Reid et al., 2019). Continuous overuse increases the deforestation rate of riparian vegetation and

69 thus increases runoff, causing changes in the stream morphology and consequently the habitat 
70 degradation. These changes affect the physicochemical parameters of the water, contributing to

71 the impoverishment of aquatic biodiversity (Etter \& Wyngaarden, 2000; Zapata et al., 2007;

72 Larson, Dodds \& Veach, 2019).

73

74 In particular, different studies have shown how mining, agricultural and cattle production

75 threaten the quality of, and access to, hydric resources (Lucia et al., 2017; Grudzinski \& Daniels, 76 2018; Mwangi et al., 2018). In Colombia, agriculture, cattle production and mining have put both

77 the quality and availability of hydric resources at risk over the last decade (Chará-Serna et al., 78 2015; Villada-Bedoya et al., 2017; Villada-Bedoya, Triana-Moreno \& Dias, 2017; Ramírez et al., 2018). These activities threaten the lotic systems of the Andes, where the human population of the country is concentrated (Murtinho et al., 2013; Guevara, 2014; Chará-Serna et al., 2015).

In recent decades, aquatic macroinvertebrates (AMI) have been widely studied as effective bioindicators in the evaluation of the impact of human activities on freshwater ecosystems (e.g.,

84 González, Basaguren \& Pozo, 2003; Prat et al., 2009; Buss et al., 2017). At both community and

85 population level, these organisms are highly sensitive to changes in the physicochemical properties of the water and to habitat quality (Alonso \& Camargo, 2005; Carter, Resh \&

87 Hannaford, 2017). Different studies in the Neotropics have evaluated the effects of mining, 88 agricultural and cattle production activities on AMI (e.g., Villamarín-Flores, 2008; Hepp et al., 89 2010; Mesa, 2010; Miserendino \& Masi, 2010; Ordóñez, 2011; Egler et al., 2012; Terneus, 90 Hernández \& Racines, 2012; Fierro et al., 2015). In recent years, studies exploring the effects of 91 cattle production, agriculture and mining activities on the AMI communities have increased in 92 Colombia (e.g. Chará \& Murgueitio, 2005; Feijoo, Zúñiga \& Camargo, 2005; Galindo-Leva et 
93 al., 2012; Gómez, 2013; Villada-Bedoya, Triana-Moreno \& Dias, 2017; Ramírez et al., 2018),

94 and have documented changes in the ecological attributes of the AMI as a consequence of

95 anthropogenic alterations to inland water resources.

97 In the case of species richness, greater values have been recorded in reference streams compared 98 to those with an influence of mining, agriculture or cattle production (Feijoo, Quintero \& 99 Fragoso, 2006; Egler et al., 2012; Terneus, Hernández \& Racines, 2012), mainly due to the 100 reduction in riparian vegetation and introduction of polluting substances. In terms of abundance

101 (or density), some studies have recorded greater values in sites with anthropogenic impacts

102 compared to those with greater quantities of surrounding vegetation (Chará \& Murgueitio, 2005;

103 Miserendino \& Masi, 2010). This is due to the dominance of certain taxa, as has been observed

104 in streams dominated by agriculture (Egler et al., 2012) and cattle production (Mesa, 2010;

105 Giraldo et al., 2014). Likewise, AMI composition also presents important differences between

106 streams with and without evident anthropogenic impact (Hepp et al., 2010).

108 Among the activities that most degrade the aquatic ecosystem, mining has been considered to

109 have serious effects on water quality and quantity due to mining wastes and the ecological

110 impairment of habitats (Cidu, Biddau \& Fanfani, 2009; Wright \& Ryan, 2016). Channel

111 diversion and the removal of organic matter and sediments affect the availability of refuge and

112 food for benthic organisms, making it difficult to colonize and/or recover long-term communities

113 (Milner \& Piorkowsk, 2004). However, few studies have conducted simultaneous evaluation of

114 the effects of mining, agriculture and cattle production in Andean streams (Villada-Bedoya et al.,

115 2017; Villada-Bedoya, Triana-Moreno \& Dias, 2017; Ramírez et al., 2018). It is important to 
116 recognize that the Neotropical region presents a wide variety of climatic conditions and habitat

117 heterogeneity, for which reason the diversity patterns are dynamic and can be influenced by

118 many factors (land use, local geography, availability of riparian vegetation, among others).

119 Further knowledge of the patterns of AMI density and diversity is therefore necessary (Guevara, 120 2014; Buss et al., 2017).

121

122 This study evaluated the density, diversity and compositional dissimilarity of the AMI in

123 contrasting headwater streams of the Colombian Andes; two near-pristine streams, and one

124 stream in zones with agricultural, cattle production and gold mining activities, in the Chinchiná

125 river basin (Caldas, Colombia). According to the assumed impact of each productive land use,

126 we expected that: 1) AMI density will increase from the two reference streams to those of

127 agriculture, cattle production and mining, 2) this increase in density will reflect an increased

128 dominance of taxa that are tolerant to the water pollution, and 3) a maximum impoverishment of

129 AMI diversity will be found in the zone with gold mining activity.

130

\section{Materials and Methods}

133 Study area. The selected streams are located on the western slope of the central cordillera of the

134 Colombian Andes, in the municipalities of Villamaría and Manizales (Caldas, Colombia), and

135 are tributaries of the Chinchiná river basin. Five sampling zones were selected, three of these

136 zones had productive impacts (agriculture, cattle production and gold mining) while the other

137 two were of reference condition; i.e., streams with no evident local anthropogenic impacts (Fig.

138 1). In each zone, AMI sampling was carried out along $100 \mathrm{~m}$ of the streams. 
140 Reference 1 (Ref1): Located in the stream La Elvira, sector Maltería (Manizales: 0503'10.9"N,

$\left.14175^{\circ} 24^{\prime} 33.6^{\prime \prime} \mathrm{W}\right)$ at $2766 \mathrm{~m}$ asl. This area presents riparian vegetation of greater than $15 \mathrm{~m}$ in

142 width, mainly comprising herbaceous plants, shrubs and trees. The most representative plant

143 species include Aiouea sp., Clethra revoluta Ruiz and Pav., Dunalia solanacea Kunth, Miconia

144 superposita Wurdack and Verbesina nudipes S.F. Blake.

146 Reference 2 (Ref2): Located in the stream La Floresta (Villamaría: 05'42.1"N, 75³1'10.9"W)

147 at $1720 \mathrm{~m}$ asl, close to agricultural zones and used as an area of recreation. Its riparian vegetation

148 is more than $15 \mathrm{~m}$ in width and presents elements characteristic of conserved forest (Guariguata

$149 \&$ Ostertag, 2002), such as large trees of the families Moraceae (Ficus sp., Coussapoa duquei

150 Standley), Lauraceae (Nectandra sp.) and Boraginaceae (Cordia panamensis L. Riley).

152 Cattle production (CP): Located in the stream Cimitarra, sector Maltería (Manizales:

$15305^{\circ} 04^{\prime} 32.0^{\prime \prime} \mathrm{N}, 75^{\circ} 24^{\prime} 0.60^{\prime \prime} \mathrm{W}$ ) at $2550 \mathrm{~m}$ asl. It is surrounded by grazing pastures, although the

154 cattle have no access to the stream due to the presence of a strip of vegetation of approximately 3

$155 \mathrm{~m}$ in width on both banks, which is dominated by species of early succession such as: Baccharis

156 latifolia Ruiz and Pavón, Miconia superposita Wurdack, Rubus glaucus Benth, Aphelandra

157 acanthus Nees, Solanum phaeophyllum Werderm and Tibouchina lepidota Bonpl. In addition,

158 two introduced plant species were recorded: Pennisetum clandestinum Hochst. ex Chiov

159 (Poaceae), cultivated as pasture, and Lachemilla orbiculata Ruiz \& Pav. (Rosaceae), a plant

160 species abundant in grazing pastures of cold climates (Vargas, 2002).

161 
162 Agriculture (Agr): Corresponding to the stream "Don Alonso" (Villamaría: 0501'50.79"N,

$16375^{\circ} 31^{\prime} 39.59^{\prime \prime} \mathrm{W}$ ) at $1849 \mathrm{~m}$ asl. The riparian vegetation is practically absent (only small shrubs,

164 grasses, and sparse herbaceous plants persist). In addition, this area also has closer vegetable

165 gardens in which the following species are cultivated in alternation with the following species:

166 Brassica oleracea var. capitata Linnaeus and Brassica oleracea var. italica Linnaeus, Sechium

167 edule. (Jacq.) Sw., Musa velutina H. Wendl. and Drude, Guadua angustifolia Kunth, Urera

168 baccifera (L.) Gaudich., Piper cf. crassinervium Kunth, Montanoa quadrangularis Schultz

169 Bipontianus, Cecropia angustifolia Trécul.

170

171 Mining (Mi): Located on the stream La Elvira (Manizales: 0503'4.4"N, 75²4'33.1"W) at 2725

$172 \mathrm{~m}$ asl. Its riparian zone is fragmented by land use change through activities of auriferous mining

173 extraction using mercury. The stream presents vegetation comprising grazing pastures and

174 secondary forest with an approximate width of 1 to $2 \mathrm{~m}$, dominated by grasses (Pennisetum

175 clandestinum Hochst. ex Chiov), herbaceous plants (Coniza bonariensis (L.) Cronquist),

176 Hypochaeris radicata L., Taraxacum officinale G. H. Weber ex Wigg, Lachemilla orbiculata

177 Ruiz and Pavón, Plantago major L., Gunnera brephogea Linden \& André) and some juvenile

178 trees (Baccharis latifolia Ruiz and Pavón and Miconia cf theaezans Bonpl.).

179

180 Collection of organisms. The AMI density (ind $/ \mathrm{m}^{2}$ ) and diversity, and composition of RTUs,

181 were evaluated based on Rapid Bioassessment Protocols (RBP) (Barbour et al., 1999). We used a

182 Surber net $(30 \times 30 \mathrm{~cm}$, mesh size $250 \mu \mathrm{m})$ with three replicates in each of three substrates (leaf

183 litter, rock and sediment; Aazami et al., 2015) during six sampling events per stream (between

184 February 2014 and February 2015), giving a total of 54 samples per zone. The collected material 
185 was fixed in vials containing 96\% alcohol and the AMI identified to the lowest practical

186 taxonomic level (usually genus) using the taxonomic keys of Merritt \& Cummins (1996),

187 Domínguez et al. (2006) and Domínguez \& Fernández (2009). Specimen collection permits were

188 regulated by Resolution 1166 of October $9^{\text {th }}, 2014$, issued by the National Environmental

189 Licenses Authority (ANLA, by its Spanish acronym) of Colombia and by Decree 1376 of June

$19027^{\text {th }}, 2013$ from the Colombian Ministry of Environment and Sustainable Development. The

191 material was deposited in the Entomological Collection of the Programa de Biología of the

192 Universidad de Caldas - CEBUC (certified collection under register: No 188 in the Registro

193 Nacional de Colecciones Biológicas - RNC administered by Instituto de Investigación de

194 Recursos Naturales Alexander von Humboldt).

195

196 Hydrological, physicochemical and bacteriological parameters. The environmental

197 characterization of the sampling streams involved 27 different hydrological, physicochemical

198 and bacteriological (HPCB) parameters and elevation (m asl). Among the hydrological

199 parameters, water flow volume $\left(\mathrm{m}^{3} / \mathrm{s}\right)$ was measured in each sampling event and mean

200 precipitation (mm/week) in each month of sampling was recorded (IDEAM, 2015). In February,

201 July and November 2014, the following water and stream parameters were measured (in situ,

202 Table S1): velocity $(\mathrm{m} / \mathrm{s})$, width $(\mathrm{m})$, depth $(\mathrm{cm})$, temperature $\left(\right.$ Temp, $\left.{ }^{\circ} \mathrm{C}\right), \mathrm{pH}$, conductivity

203 (Con, $\mu \mathrm{S} / \mathrm{m}$ ) and dissolved oxygen (DO, $\mathrm{mg} / \mathrm{L})$. Temperature, $\mathrm{pH}$ and conductivity were

204 measured with an OAKLON PH/CON 300 multiparameter device, while dissolved oxygen was

205 measured with a Lutron do-5510 dissolved oxygen meter. Water samples were taken and

206 transported to the IQ\&A (Ingenieros químicos y asociados S.A., Manizales, Colombia) certified

207 laboratory for determination of the following parameters (Table S1): chlorides (Ch, mg/L), 
208 sulphates $\left(\mathrm{SO}_{4}, \mathrm{mg} / \mathrm{L}\right)$, nitrites $\left(\mathrm{NO}_{2}, \mathrm{mg} / \mathrm{L}\right)$, phosphates $\left(\mathrm{PO}_{4}, \mathrm{mg} / \mathrm{L}\right)$, fats and oils $(\mathrm{FO}, \mathrm{mg} / \mathrm{L})$,

209 biochemical oxygen demand (BOD, mg/L), chemical oxygen demand (COD, mg/L), total

210 dissolved solids (TS, mg/L), total suspended solids (TSS, mg/L), ammoniacal nitrogen $\left(\mathrm{NH}_{3}-\mathrm{N}\right.$,

$211 \mathrm{mg} / \mathrm{L})$, aluminum (Al, mg/L), mercury (Hg, mg/L), total iron (Fe, mg/L), lead (Pb, mg/L),

212 cyanide (Cy, mg/L), boron (B, mg/L), Escherichia coli (Ecoli, CFU/100 mL) and total coliforms

213 (Tc, CFU/100 mL) (Chará, 2003; Sánchez, 2004).

214

215 Data analysis. The AMI density values among sampling zones were analyzed with a non-

216 parametric repeated measures Friedman test $(n=6$ sampling events $)$ and particular differences

217 among streams were identified with a post-hoc Nemenyi test (Zar, 2010). Diversity was

218 estimated as the effective number of RTUs or diversity order q ( ${ }^{\mathrm{q}} \mathrm{D}$; Jost, 2006):

$$
\mathrm{q} \mathrm{D}=\left(\sum_{i=1}^{S} p_{i}^{q}\right)^{1 /(1-q)}
$$

Where pi is the relative abundance (proportional abundance) of the $i$-th RTU, S is the number of

221 RTUs and the q-value is the order of the diversity. When $\mathrm{q}=0$, richness is obtained. When $\mathrm{q} \approx 1$,

222 the effective number of equally common genera is obtained. This is equivalent to the exponential

223 of the Shannon index of entropy and does not present bias as a result of the presence of either

224 rare or abundant RTUs in the sampling. Finally, when $\mathrm{q}=2$, the value of diversity indicates the

225 effective number of the more abundant RTUs in the sampling and is equivalent to the inverse of

226 the Simpson index of entropy (Moreno et al., 2011).

228 Since the continuous variable of density was used as an abundance measure, estimation of

229 sample coverage ( $\hat{\mathrm{C}} \mathrm{n}$, see Chao \& Jost, 2012) per stream was not required prior to making the

230 diversity comparisons. In each case, we obtained a completeness of $100 \%$ (absence of 
231 singletons), and the diversity comparison was therefore made directly with the observed values

232 of ${ }^{9} \mathrm{D}$. The $\mathrm{CI} 95 \%$ of each expression of diversity $\left({ }^{0} \mathrm{D},{ }^{1} \mathrm{D},{ }^{2} \mathrm{D}\right)$ was used as a statistical criterion,

233 in which absence of overlap between the CI 95\% indicated significant differences between the

234 values of diversity (Cumming, Fidler \& Vaux, 2007; Chao et al., 2020). Estimation of ${ }^{\mathrm{q}} \mathrm{D} \pm \mathrm{CI}$

$23595 \%$ was conducted with the package iNEXT of R (Hsieh, Ma \& Chao, 2015).

237 By expressing diversity as the effective number of RTUs and making comparisons under the same and maximum sample coverage $(100 \%)$, the replication principle is met and it is possible to

239 calculate the magnitude of the difference in diversity (MD = Sampling Site 2 / Sampling Site 1) among communities (Jost, 2006; Moreno et al., 2011). It is thus possible to determine how many times one zone is more or less diverse than another. In addition, comparison of ${ }^{\mathrm{a}} \mathrm{D} \pm \mathrm{CI} 95 \%$ under the effective numbers of RTUs eliminates estimation bias due to the high density of certain aquatic insect groups, such as the dipterans (e.g., Chironomidae). It would be impossible to avoid this bias using the classic protocol for the use of rarefaction curves, which relies on a comparison based on minimum sample size or minimum abundance. To evaluate the differences in density and the incidence of dominant taxa tolerant to water contamination, rank-density curves were constructed per sampling zone. On the x-axis, RTUs were ranked in descending order according to density (y-axis in logarithmic scale). These curves not only allow visualization of the distribution of density among the RTUs but also determination of which taxa disappear or appear and the relative positions they occupy in each sampling area, according to their density. This

251 information, together with the \% MD, may be more useful for the ecological diagnostic of the

252 effects of anthropogenic impact on water conditions (Feinsinger, 2001). 
254 The compositional dissimilarity of AMI RTUs was examined with a non-metric

255 multidimensional scaling (nMDS) based on the Bray-Curtis index (Quinn \& Keough, 2002). An

256 ANOSIM was used to determine whether the compositional dissimilarity was greater among than

257 within zones, and the contribution of the RTUs to the dissimilarity was subsequently established

258 using a SIMPER (Quinn \& Keough, 2002). The patterns of density, diversity and compositional

259 dissimilarity were discussed with respect to HPCB parameters. First, we used a Spearman

260 correlation test to examine how changes in AMI density were related to flow and precipitation

261 (Table S2). Secondly, since the HPBC was measured in only three sampling moments (i.e., Feb,

262 Jul, Nov 2014), we performed a CCA analysis to evaluate the association patterns among RTUs,

263 sites and HPBC parameters regarding pair-consecutive AMI sampling events: Feb14+Apr14;

264 Jul14+Sept14; Nov14+Feb15. This temporal grouping of data was also used for the

265 compositional dissimilarity analyses (see above). To avoid collinearity among HPBC parameters,

266 we applied the Variance Inflation Factor (VIF) and HPBC parameters with VIF $>10$ were thus

267 excluded from the CCA analysis (Neter, Wassermn \& Kutner, 1990). All statistical analysis was

268 performed using R version 3.2.1 (R Core Team, 2015; Table S3, R-code, and input data in Data 269 S1).

270

271 Results

272 A total of 7483 organisms were collected, belonging to 14 orders, 42 families and 71

273 recognizable taxonomic units (RTUs), of which 57 were at genus and 14 at family level (Table

274 1). The stream with the greatest AMI density was Reference 2 with $1808.7 \mathrm{ind} / \mathrm{m}^{2}$, followed by

275 Reference 1 with $1219.8 \mathrm{ind} / \mathrm{m}^{2}$. These were followed by the Cattle production-dominated

276 stream with $1106.5 \mathrm{ind} / \mathrm{m}^{2}$, then the Mining stream with $1074 \mathrm{ind} / \mathrm{m}^{2}$ and Agriculture stream

Peer] reviewing PDF | (2019:06:38347:2:0:NEW 25 Jun 2020) 
277 with $852.1 \mathrm{ind} / \mathrm{m}^{2}$. However, density was significantly higher only in the zone Reference $2(\mathrm{Fr}=$

$2783.10, \mathrm{df}=29, \mathrm{p}$-value $=0.0163$; Nemenyi post hoc test, p-value $=0.0163)($ Fig. $2 \mathrm{~A})$. In all of the

279 sampling areas, the rank-density curves showed low equality among the communities, where less

280 than $50 \%$ of the RTUs presented densities higher than $25 \mathrm{Inds} / \mathrm{m}^{2}$ (i.e., dominant RTUs) (Fig. 3).

281 Apart from the agricultural impact zone (Agr), Baetodes and Anchytarsus were common

282 dominant RTUs among the sampling zones, in which Baetodes always occupied the first two

283 positions, even in the Cattle production (CP) and Mining (Min) streams (Fig. 3). In the

284 Agriculture-dominated stream, only three RTUs made up the group of dominant taxa: Simulium,

285 Dugesia, and Rhagovelia (Fig. 3).

286

287 According to the $95 \% \mathrm{CI}$, the agricultural zone presented the lowest significant values for the 288 three expressions of diversity ( $\left.{ }^{\mathrm{a} D}\right)$ (Fig. 2B). In contrast, the other sampling zones differed 289 according to diversity expression. In the case of the observed richness of the RTUs $\left({ }^{0} \mathrm{D}\right)$, the 290 zones were ordered as follows: Reference $2>$ Reference $1>$ Cattle production $\approx$ Mining) (Fig.

291 2B). In particular, Reference 2 presented an increase in RTU richness that was between 1.3 (Ref2 292 vs. Ref1) and 4.3 (Ref2 vs Agr) times greater than the other sampling zones. Regarding the 293 effective number of equally common RTUs $\left({ }^{1} \mathrm{D}\right)$, the following pattern was obtained: (Reference $2942 \approx$ Cattle production) $>$ Reference $1>$ Mining. In this case, Reference 2 and Cattle production 295 were between 1.3 and 3.8 times more diverse than other zones. In relation to the effective 296 number of the most abundant RTUs, the zones were ordered in a decreasing pattern $\left({ }^{2} \mathrm{D}\right)$ : Cattle 297 production $>$ Reference $2>$ Reference 1 $>$ Mining (Fig. 2B), where the magnitude of the difference 298 ranged from 1.1 (CP vs Ref2) to 4.3 (CP vs. Agr)-fold. 
300 No tendency of significant variation was detected in AMI density with respect to water flow (p-

301 value: $0.18-0.94)$ and precipitation (p-value: $0.17-0.82$ ) (Figures S1 and S2). The

302 physicochemical parameters of the water in the studied streams were within the quality

303 thresholds admissible for human and domestic use (articles 38 and 39 of the Colombian Decree

3041594 of 1984). The only exceptions were presented during the third sampling (July 2014), which

305 produced values of total coliforms and E. Coli that exceeded admissible levels in the Agriculture

306 stream (410,600 CFU/100 mL and 2,417 CFU/100 mL, respectively), and exceeded admissible

307 levels for total coliforms in the Mining stream (22,470 CFU/100 ml).

308

309 Eight RTUs were shared by the five sampling zones: Baetodes, Simulium, Anchytarsus,

310 Smicridea, Tipula, Culoptila and the subfamilies Chironominae and Orthocladiinae. The nMDS

311 analysis evidenced separation among the different sampling streams (Fig. 4; Stress $=0.13$ ),

312 which is consistent with that found in the ANOSIM. Both tests showed that there were

313 differences among all of the streams in terms of composition (ANOSIM: $\mathrm{R}=0.673$, $\mathrm{p}$-value $=$

314 0.001). The SIMPER analysis indicated that Baetodes, Simulium and Smicridea were the taxa

315 that contributed most to the differences found among the studied streams. The CCA presented an

316 appreciable association between environmental parameters, sites and macroinvertebrates (Fig. 5:

317 CCA $1+$ CCA2 $=63.2 \%$ of explained variance), where the Agricultural zone had

318 physicochemical profiles and biotic components that were differentiated and remained separated.

319 The Agricultural zone also presented the highest values of TS (Fig. 5) and lowest values of DO

320 (Table S1), associated with the highest values of density of the taxa Simulium, Chimarra,

321 Dugesia, Rhagovelia and Calopterygidae, while some Ephemeroptera and Coleoptera

322 (Anchytarsus and Heterelmis) were practically absent from this stream (Table 1). The Cattle 
323 production and both Reference streams were associated with high values of DO, in addition to

324 the high density of the RTUs Baetodes, Mayobaetis, Andesiops and Anchytarsus (Fig. 5; Table

325 S1). The Mining stream, however, was strongly associated with the highest phosphate values and

326 high values of TS, as in the Agriculture stream (Fig. 4), and presented a decrease in the majority

327 of the previously mentioned RTUs.

328

329 Discussion

330 The Agricultural zone had a greater effect on AMI diversity (lowest values of richness and

331 density) than the Mining zone, which did not follow the expected pattern in our study. These

332 results are probably associated with the traditional horticultural practices (e.g., soil preparation

333 and use of agrochemicals) over several years in zones of the Chinchiná river basin (Caldas,

334 Colombia: Meza-S. et al., 2012; Chará-Serna et al., 2015; Llano et al., 2016); a land use situation

335 that traditionally occurs throughout the Andes (Mesa, 2010; Guevara, 2014; Vimos-Lojano et al.,

336 2017). The expansion of agricultural land use strongly reduces the presence of totally pristine

337 headwater ecosystems in many mountainous countries (Vimos-Lojano et al., 2017), where

338 several cultivated areas converge toward mainstream channels (Chará et al., 2007; Chará-Serna

339 et al., 2015). With respect to the density, and contrary to expectation, the dominance of some

340 RTUs tolerant to water contamination did not imply a linear increase in the total density of RTUs

341 from the reference areas to the streams with anthropic impact.

342

343 The higher AMI values of richness and density recorded in the reference and cattle production

344 zones could be linked to the presence of riparian vegetation and its importance in buffering

345 environmental impacts (e.g., Lenat, 1984; Rivera, 2004; Burdet \& Watts, 2009; Egler et al., 
346 2012). However, the stream Reference 2 presented the highest values, which is possibly due to

347 the greater differential contribution of leaf litter from speciose riparian vegetation, producing a

348 greater availability of coarse organic benthic resources in this zone (Gutiérrez-López, Meza-

349 Salazar \& Guevara, 2016). It is important to note that the agricultural zone did not have riparian

350 vegetation, which may be the reason for the lowest richness and density values found there, as is

351 the case in other studies (e.g., Lenat, 1984; Lenat \& Crawford, 1994; Hepp et al., 2010; Egler et

352 al., 2012). Although this study was not aimed at testing the role of the riparian vegetation, this

353 result partially coincides with the notion that removal of this vegetation can have both direct and

354 indirect effects on AMI abundance (Lenat, 1984; Egler et al., 2012), due to the consequent

355 degradation of both habitat and water quality (Chará et al., 2007). Indeed, low values of richness

356 in zones of agriculture with similar circumstances have been previously reported by other

357 authors (e.g., Lenat, 1984; Lenat \& Crawford, 1994; Hepp et al., 2010; Egler et al., 2012), who

358 argue that deterioration in water quality influences the number of aquatic invertebrate taxa.

360 The diversities ${ }^{1} \mathrm{D}$ and ${ }^{2} \mathrm{D}$ presented a similar pattern, due to the high importance or dominance

361 of the most abundant RTUs in each of the studied streams. The high diversity in the Reference 2

362 and Cattle production streams, as well as the significantly greater diversity in the Reference 1

363 compared to the Mining and Agriculture streams, could also be related to the presence of riparian

364 vegetation since, although the Cattle production zone does present effects related to this activity,

365 the strips (ca. $3 \mathrm{~m}$ in width) of vegetation that exist on both sides of the stream may act to

366 diminish these effects on the AMI community. Niemi \& Niemi (1991) indicate that vegetation

367 has a positive effect on streams immersed in cattle production zones, since it acts as a barrier to

368 the animals and traps sediments that are transported towards the water bodies by surface runoff. 
369 Consequently, the Mining and Agriculture streams presented the lowest values of diversity,

370 being significantly lower in the Agriculture stream. These land use changes, in which riparian

371 vegetation is replaced by human activities such as mining and agriculture, lead to a constant

372 alteration of the physical characteristics of the water bodies and can thus directly or indirectly

373 influence changes in the spatial and/or temporal diversity of the AMI (Tomanova \& Usseglio-

374 Polaterra, 2007; Domínguez \& Fernández, 2009).

375

376 For all three diversity expressions (i.e., $\left.{ }^{0} \mathrm{D},{ }^{1} \mathrm{D},{ }^{2} \mathrm{D}\right)$, the lowest values were presented in the

377 stream influenced by agricultural activities. Chará-Serna et al. (2015) reported that one of the

378 most important indirect consequences of agricultural practices for the AMI community is an

379 increase in the values of ammoniacal nitrogen $\left(\mathrm{NH}_{3}-\mathrm{N}\right)$. The present study did not find values of

380 this parameter as high as those reported by other authors in Neotropical streams (Mesa, 2010;

381 Vázquez, Aké-Castillo \& Favila, 2011; Chará-Serna et al., 2015). However, Gücker et al. (2009)

382 explain that, although the values in streams with agriculture may be low, they still exceed those

383 in zones with no impact. This coincides with our results, in which the values of $\mathrm{NH}_{3}-\mathrm{N}$ in the

384 Agriculture stream $(0.323 \mathrm{mg} / \mathrm{L})$ exceeded those of both Reference zones (Reference 1: 0.153

$385 \mathrm{mg} / \mathrm{L}$; Reference 2: $0.175 \mathrm{mg} / \mathrm{L})$.

386

387 In the evaluated streams, the high representativity and contribution of Baetodes, Andesiops,

388 Simulium and Smicridea, as well as the subfamily Orthocladiinae, coincide with the results of

389 González et al. (2012) and Meza-S et al. (2012) in the Chinchiná river basin, in which these taxa

390 presented a high abundance. Baetodes, Simulium, Smicridea and the subfamily Orthocladiinae

391 have a wide distribution in Neotropical basins, covering broad elevational ranges (Sganga \& 
392 Angrisano, 2005; Sganga \& Fontanarrosa, 2006). On the other hand, the structure of the AMI

393 communities suggests that the anthropic disturbance of the evaluated streams, except for in the

394 Agricultural zone, has not yet crossed a point of no return. This is because of the lack of

395 association between the dominant RTUs and a drastic reduction in the richness of RTUs, or with

396 a phenomenon of hyperabundance of dominant RTUs (Fig. 3). This result suggests that the areas

397 with impact from Cattle production and Mining have not yet been homogenized until limiting the

398 availability of different resource types. However, these results should be treated with some

399 caution, since the changes in the structure of the community of AMIs and the incidence of

400 tolerant RTUs may reflect the effect of factors or biases in operation, rather than the specific

401 anthropic impact. Moreover, unlike rivers in low-lying areas, Andean streams are very complex

402 due to the topography and orography of the landscapes. The low evenness in the communities

403 may therefore reflect the complex dynamics of mountain rivers, which include high fluctuations

404 in flows and sediment deposition (organic and inorganic), given the high runoff rate (Aguirre-

405 Pabón et al., 2012; González et al., 2012).

406

407 The nMDS analysis showed a clear separation between Agriculture and the other sampled zones.

408 This is due to the high dominance of Simulium, which presents lower values than other streams,

409 as well as the absence of pollution intolerant taxa, such as Anacroneuria, Marilia and

410 Camelobaetidius (Zúñiga \& Cardona, 2009). This result demonstrates that the presence of heavy

411 agricultural activity in the sampling zones has a strong effect on the AMI community. Roldán \&

412 Ramírez (2008) indicate that a river that has suffered alterations to its natural conditions through

413 contamination processes will reflect these effects in changes to the composition and structure of

414 its aquatic biota. Likewise, García \& Rosas (2010) explain that agricultural activities can cause 
415 the loss of sensitive taxa, as indeed was the case in our study. The similarity between the

416 Reference 1 and Mining streams is due to the fact that both conditions were found on the same

417 stream (i.e., La Elvira stream). Spatial proximity between sampling sites can potentially mask the

418 specific effect of a disturbance on the AMI community; an effect that is maximized if the sites

419 are located on the same watercourse (Tolonen et al., 2017). The density and diversity of AMI in

420 the Mining sampling point may therefore be influenced by proximity to the Reference 1

421 sampling site. Although our sampling design did not adequately detect the effect of spatial

422 autocorrelation between sampling stations, the results indicated that spatial proximity does not

423 dampen the impact of Mining on the AMI community and on the water conditions in terms of the

424 HPCB parameters. The compositional dissimilarity between the Mining and Reference 1

425 sampling sites is produced by the presence of the genera reported in Reference 1, which are

426 relatively less abundant in the Mining stream (e.g., Smicridea, Andesiops and Nanomis; Fig. 5).

427 Consequently, the CCA evidenced a clear separation between Mining and Reference 1, where

428 the former presents groups tolerant to conditions of high-water contamination by mining activity

429 (e.g., some Chironomidae, Tipulidae and Empididae) (see Pond et al., 2014). These results

430 coincide with the idea that point scales, variation in abundance or incidence of macroinvertebrate

431 groups can be strongly modulated by the presence and availability of microhabitats (e.g.,

432 Burgazzi, Giareschi and Laini, 2019).

433

434 The isolation of the Agriculture zone in the CCA, and its high values of TS (310.7 \pm 209.8$)$ and

435 lowest values of DO (2.3 \pm 0.8$)$, reflect the negative impact of this activity on the stream and

436 associated biota. High concentrations of TS were found in both the Agricultural and Mining

437 streams, reducing the entry of light to the ecosystem and affecting the energy flow of the system, 
438 which lowers its productivity levels as a consequence (Vázquez, Aké-Castillo \& Favila, 2011).

439 Furthermore, the increase in TS is related to the sedimentation rate (Vásquez Zapata, 2009) and

440 the increase in fine sediment can, in turn, be a more significant stressor to macroinvertebrate

441 assemblages than increased nutrient concentrations, in streams around agricultural areas (Ladrera

442 et al., 2019). Moreover, this variable can affect a different group of AMI, for example, taxa

443 adapted to swim, scrape or shred, species that respire by plastron, gills and also Coleopterans

444 dependent on a bubble or plastron to breath (Hauer \& Resh, 1996; Rabeni et al., 2005; Ladrera et

445 al., 2019). In contrast, invertebrates living in the mud, burrowers and filter-collectors can be

446 favored because they feed on fine sediment.

448 Low DO promotes the loss of richness, increasing the density of tolerant organisms, as

449 mentioned by Jacobsen \& Marín (2008). Both variables (TS and DO) could explain the high

450 abundance of relatively tolerant filter-collector organisms such as Simulium and Chimarra, even

451 though Simulium is generally associated with watercourses with a high concentration of oxygen

452 (Roldán, 1996; Domínguez \& Fernández, 2009; Zúñiga \& Cardona, 2009; Villada et al., 2017).

453 However, some Simulium species may be more tolerant than others, so it is important to advance

454 the taxonomic knowledge of the group for identification to species level. On the other hand,

455 predators such as Calopterygidae, Dugesia and Rhagovelia can benefit in these environments

456 because of resource availability, as is the case with Rhagovelia that move over the water surface

457 layer, breathing atmospheric oxygen and feeding on dead or dying insects. At the same time, the 458 Calopterygidae are generally associated with substrates at the bottom of streams, where they can 459 tolerate low concentrations of dissolved oxygen in water (Domínguez \& Fernández, 2009). 
461 The Cattle production and Reference 2 zones had associated high values of DO (9.3 \pm 3.3 and

$4625.4 \pm 0.63$, respectively), suggesting that these were the most conserved zones in the study, with

463 the greatest richness of species sensitive to contamination. Zúñiga \& Cardona (2009) classified

464 Anchytarsus as sensitive to pollution, which is supported by our finding that this genus presented

465 higher density in the Reference zones. Regarding Ephemeroptera, several authors indicate that

466 the many genera in the group are sensitive to contamination (e.g., Zedcová et al., 2014;

467 Akamaqwuna et al., 2019). Buss \& Salles (2006) highlighted the importance of including the

468 species level for the establishment of sensitivity in water quality monitoring programs. The

469 highest phosphate $(1.2 \pm 0.62)$ and TS (394.7 \pm 210$)$ values found in the Mining zones indicate the

470 deterioration that this activity can generate in aquatic ecosystems (Wright \& Ryan, 2016),

471 affecting the survival of some genera of macroinvertebrates (Ramírez et al., 2018).

472

473 In general, low values of precipitation and water flow volume were associated with high AMI

474 densities in the studied streams. Concomitant results have been found in other small Colombian

475 streams (Rodríguez- Barrios et al., 2007; Longo et al., 2010; Tamaris-Turizo et al., 2013).

476 However, we have no evidence of high variation in density related to either of these

477 environmental variables. Minshall \& Robinson (1998) explain that a constant climate pattern, or

478 one of little variation, in the riparian environment translates into lower variability in the AMI

479 dispersion dynamic. Moreover, Smith \& Lamp (2008) suggest that the abundance and

480 composition of the AMI community are influenced more by land use than by the seasons of high

481 and low rains. This suggestion is consistent with the results of our study.

482

483 Despite our attempt to continuously evaluate both physicochemical and biological parameters, 
484 mining and agriculture activities present highly variable management practices (e.g., frequency

485 and quantity of chemicals used). It is difficult to control this anthropogenic factor, which occurs

486 jointly with natural hydrological patterns (see Friberg, 2014) in the selected small streams.

487 Although these are key elements (i.e., the contribution of natural and anthropogenically-induced

488 changes) for consideration in the patterns of stream macroinvertebrate distribution (e.g.,

489 Domisch et al., 2017; Kakouei et al., 2018), this aspect was beyond the scope of the present

490 study due to logistical restrictions. Further studies are therefore necessary to adequately evaluate

491 the variability of AMI due to both anthropogenic and natural pressures. It is recommended that

492 future studies employ a larger number of spatial replicates incorporating the effects of each of

493 the impacts and that a rigorous search of the zones of reference is conducted in order to ensure

494 the absence of anthropogenic effects. In addition, evaluation of the heavy metals present in the

495 sediment is recommended, since this is where their concentration is likely to be highest (e.g.,

496 Dickson et al., 2019).

497

498 Conclusions

499 Contrary to our central hypothesis, the results show that the Agricultural zone had the lowest

500 macroinvertebrate density and diversity. In this sense, beyond the environmental diagnosis based

501 on physicochemical and bacteriological variables, the use of diversity measures ( $\left.{ }^{9} \mathrm{D}\right)$ can be a

502 useful tool to evaluate the impact of human activity on freshwater in-stream biota, since they

503 allow adequate quantification of changes in the structure of AMI communities, using units with

504 biological sense.

505

506 Acknowledgements 
507 The authors are grateful to the Universidad de Caldas, Aguas de Manizales S.A. and to members

508 of the Bionat research group for their collaboration in the fieldwork. We also thank the

509 anonymous reviewers and Editor for all the support and improvements provided during the

510 reviewing process of our manuscript.

511

512 Funding statement. This study was funded by the Vicerrectoría de Investigaciones y Postgrados

513 of the Universidad de Caldas and the "Departamento Administrativo de Ciencia, Tecnología e

514 Innovación” (COLCIENCIAS; Project 1127-569-34668).

515

516 


\section{References}

518

519 Aazami J, Esmaili-Sari A, Abdoli A, Sohrabi H, \& Van den Brink PJ. 2015. Monitoring and 520 assessment of water health quality in the Tajan River, Iran using physicochemical, fish and 521 macroinvertebrates indices. Journal of Environmental Health Science and Engineering 13(1): 29 522 DOI: $10.1186 / \mathrm{s} 40201-015-0186-y$.

523

524 Aguirre-Pabón J, Rodríguez-Barrios J, \& Ospina-Torres R. 2012. Deriva de macroinvertebrados 525 acuáticos en dos sitios con diferente grado de perturbación, río Gaira, Santa Marta - Colombia. 526 Intropica 7: 9-19.

Akamagwuna F, Mensah P, Nnadozie C, Odume N. 2019. Evaluating the responses of taxa in the orders Ephemeroptera, Plecoptera and Trichoptera (EPT) to sediment stress in the Tsitsa River and 530 its tributaries, Eastern Cape, South Africa. Environmental Monitoring and Assessment. 191:694 DOI: 10.1007/s10661-019-7846-9.

532

533 Alonso A, Camargo JA. 2005. Estado actual y perspectivas en el empleo de la comunidad de 534 macroinvertebrados bentónicos como indicadora del estado ecológico de los ecosistemas fluviales 535 españoles. Ecosistemas 14(3): 87-99 DOI: 10.7818/re.2014.14-3.00.

537 Barbour MT, Gerritsen J, Snyder BD, Stribling JB. 1999. Rapid Bioassessment Protocols for Use 538 in streams and wadeable rivers: periphyton, Benthic Macroinvertebrates and Fish. Second 539 Edition. Washington: US Environmental Protection Agency. 
541 Burrdet A, Watts RJ. 2009. Modifying living space: an experimental study of the influences of

542 vegetation on aquatic invertebrate community structure. Hydrobiologia 618: 161-173 DOI:

543 10.1007/s10750-008-9573-z.

545 Buss D, Salles F. 2007. Using Baetidae Species as Biological Indicators of Environmental 546 Degradation in a Brazilian River Basin. Environmental monitoring and assessment. 130. 365-72 547 DOI:10.1007/s10661-006-9403-6.

549 Buss DF, Carlisle DM, Chon TS, Culp J, Harding JS, Keizer-Vlek HE, Robinson WA, Strachan

550 S, Thirion C, Hughes RM. 2015. Stream biomonitoring using macroinvertebrates around the globe:

551 a comparison of large-scale programs. Environmental monitoring and assessment, 187(1): 4132.

552 DOI 10.1007/s10661-014-4132-8.

553

554 Carter JL, Resh VH, Hannaford MJ. 2017. Macroinvertebrates as biotic indicators of 555 environmental quality. In: Lamberti GA, Hauer FR, eds. Methods in stream ecology. Academic 556 Press, 293-318.

558 Chao A, Jost L. 2012. Coverage-based rarefaction and extrapolation: Standardizing samples by 559 completeness rather than size. Ecology 93(12): 2533-2547 DOI: 10.1890/11-1952.1.

560

561 Chao A, Kubota Y, Zelený D, Chiu CH, Li CF, Kusumoto B, Yasuhara M, Thorn S, Wei CL,

562 Costello MJ, Colwell RK. 2020. Quantifying sample completeness and comparing diversities 
563 among assemblages. Ecological Research, 35(2): 292-314 DOI:10.1111/1440-1703.12102.

564

565 Chará J, Pedraza G, Giraldo L, Hincapié D. 2007. Efecto de los corredores ribereños sobre el

566 estado de quebradas en la zona ganadera del río La Vieja, Colombia. Agroforestería en las

567 Américas, 45: 72-78.

568

569 Chará J, Murgueitio E. 2005. The role of silvopastoral systems in the rehabilitation of Andean

570 stream habitats. Available at http://www.lrrd.org/lrrd17/2/char17020.htm (accessed 10 November

571 2015).

572

573 Chará JD. 2003. Manual para la evaluación biológica de ambientes acuáticos en microcuencas 574 ganaderas. Cali: CIPAV.

575

576 Chará-Serna AM, Chará J, Giraldo LP, Zúñiga MDC, Allan JD. 2015. Understanding the impacts

577 of agriculture on Andean stream ecosystems of Colombia: a causal analysis using aquatic

578 macroinvertebrates as indicators of biological integrity. Freshwater Science 34(2): 727-740

579 DOI:10.1086/681094.

580

581 Cidu R, Biddau R, Fanfani L. 2009. Impact of past mining activity on the quality of groundwater 582 in SW Sardinia (Italy). Journal of Geochemical Exploration 100: 125-132 DOI: 583 10.1016/j.gexplo.2008.02.003.

584

585 Cumming G, Fidler F, Vaux DL. 2007. Error bars in experimental biology. The Journal of cell 
586

587

588

589

590

591

592

593

594

595

596

597

598

599

600

601

602

603

604

606

608

605 Dudgeon D, Arthington AH., Gessner OM, Kawabata ZI, Knowler DJ, Lévêque C, Naiman RJ 607 Importance, Threats, Status and Conservation Challenges. Biological Reviews 81: 163-182.

biology 177(1): 7-11 DOI:10.1083/jcb.200611141

Dickson JO, Mayes MA, Brooks SC, Mehlhorn TL, Lowe KA, Earles JK, Goñez-Rodriguez L, Watson DB, Peterson MJ. 2019. Source relationships between streambank soils and streambed sediments in a mercury-contaminated stream. Journal of Soils and Sediments 19(4): 2007-2019 DOI: $10.1007 / \mathrm{s} 11368-018-2183-0$.

Domínguez E, Molineri C, Pescador M. Hubbard MD, Nieto C. 2006. Aquatic Biodiversity in Latin America, v.2: Ephemeroptera of South America. Bulgaria: Pensoft Sofia-Moscow.

Domínguez E, Fernández HR. 2009. Macroinvertebrados bentónicos sudamericanos: Sistemática y biología. Tucumán: Fundación Miguel Lillo.

Domisch S, Portmann FT, Kuemmerlen M, O'Hara RB, Johnson RK, Davy-Bowker J, Bækken T, Zamora-Muñoz C, Sáinz-Bariáin M, Bonada N, Haase P, Döll P, Jähnig SC. 2017. Using streamflow observations to estimate the impact of hydrological regimes and anthropogenic water use on European stream macroinvertebrate occurrences. Ecohydrology 10(8): e1895 DOI: $10.1002 /$ eco. 1895 606 Prieur-Richard AH, Soto D, Stiassny MLJ, Sullivan CA. 2006. Freshwater Biodiversity: DOI:10.1017/S1464793105006950. 
609

610 Egler M, Buss D, Moreira J, Baptista D. 2012. Influence of agricultural land-use and pesticides on

611 benthic macroinvertebrate assemblages in an agricultural river basin in southeast Brazil. Brazilian

612 Journal of Biology 72(3): 437-443 DOI: 10.1590/S1519-69842012000300004.

613

614 Etter A, Wyngaarden V. 2000. Patterns of Landscape Transformation in Colombia, with Emphasis

615 in the Andean Region. Ambio 29(7): 412-439 DOI: 10.1579/0044-7447-29.7.432.

616

617 Feijoo A, Zuñiga MC, Camargo JC. 2005. Signs to detect regeneration and degradation of 618 agroecosystems in the coffee growing region of Colombia. Available at 619 http://www.lrrd.org/lrrd17/3/feij17025.htm (accessed 10 November 2015).

620

621 Feijoo A, Quintero H, Fragoso CE. 2006. Earthworm Communities in Forest and Pastures of the 622 Colombian Andes. Caribbean Journal of Science 42(3): 301-310.

623

624 Feinsinger P. 2001. Designing Field Studies for Biodiversity Conservation. Washington: Island 625 Press.

626

627 Fierro P, Bertran C, Mercado M, Pena-Cortes F, Tapia J, Hauenstein E, Caputo L, Vargas-Chacoff 628 L. 2015. Landscape composition as a determinant of diversity and functional feeding groups of 629 aquatic macroinvertebrates in southern rivers of the Araucanía, Chile. Latin American Journal of 630 Aquatic Research 43(1): 186-200 DOI: 10.3856/vol43-issue1-fulltext-16.

631 
632 Friberg N. 2014. Impacts and indicators of change in lotic ecosystems. Wiley Interdisciplinary

633 Reviews: Water 1: 513-531 DOI: 10.1002/wat2.1040.

634

635 Galindo-Leva LA, Constantino-Chuaire LM, Benavides-Machado P, Montoya-Restrepo EC,

636 Rodríguez N. 2012. Evaluación de macroinvertebrados acuáticos y calidad de agua en quebradas

637 de fincas cafeteras de Cundinamarca y Santander, Colombia. Cenicafé 63(1): 70-92.

638

639 García EN, Rosas KG. 2010. Biodiversidad de insectos acuáticos asociados a la Cuenca del Río

640 Grande Manatí. Puerto Rico: Departamento de Recursos Naturales y Ambientales (DRNA).

641

642 Giraldo LP, Chará J, Zúñiga M, Chará AM, Pedraza G. 2014. Impacto del uso del suelo 643 agropecuario sobre macroinvertebrados acuáticos en pequeñas quebradas de la cuenca del río La 644 Vieja. Revista de Biología Tropical 62: 203-219 DOI: 10.15517/rbt.v62i0.15788.

645

646 González-G SM, Ramírez YP, Meza-S AM, G-Dias L. 2012. Diversidad de macroinvertebrados 647 acuáticos y calidad de agua de quebradas abastecedoras del municipio de Manizales. Boletín 648 Científico Centro de Museos de Historia Natural, 16(2): 135-148.

649

650 Gómez AS. 2013. Evaluación de la calidad ecológica del agua usando macroinvertebrados 651 acuáticos en la parte alta y media de la cuenca del río Felidia, Valle del Cauca - Colombia. Thesis, 652 Universidad Autónoma de Occidente.

653

654 González JM, Basaguren A, Pozo J. 2003. Macroinvertebrate communities along a third-order 
655 Iberian stream. Annales de Limnologie - International Journal of Limnology 39(4): 287-296 DOI:

$65610.1051 / \mathrm{limn} / 2003023$.

657

658 Gutiérrez-López A, Meza-Salazar AM, Guevara G. 2016. Descomposición de hojas y colonización 659 de macroinvertebrados acuáticos en dos microcuencas tropicales (Manizales, Colombia). 660 Hidrobiológica, 26 (3): 347-357.

661

662 Guariguata MR, Ostertag R. 2002. Sucesión secundaria. In: Guariguata MR, Kattan GH, eds. 663 Ecología y Conservación de bosques neotropicales. Costa Rica: Editorial Tecnológica, 591-623. 664

665 Guevara G. 2014. Evaluación ambiental estratégica para cuencas prioritarias de los Andes 666 colombianos: dilemas, desafíos y necesidades. Acta Biológica Colombiana 19(1): 11-24 DOI: 667 10.15446/abc.v19n1.38027.

668

669 Gutiérrez Y, Dias LG. 2015. Ephemeroptera (Insecta) de Caldas - Colombia, claves taxonómicas 670 para los géneros y notas sobre su distribución. Papéis Avulsos de Zoologia 55(2): 13-46 DOI: $671 \quad 10.1590 / 0031-1049.2015 .55 .02$.

672

673 Gücker B, Boëchat IG, Giani A. 2009. Impacts of agricultural land use on ecosystem structure and 674 whole-stream metabolism of tropical Cerrado streams. Freshwater Biology 54: 2069-2085 DOI: 675 10.1111/j.1365-2427.2008.02069.x. 676

677 Grudzinski BP, Daniels MD. 2018. Bison and cattle grazing impacts on grassland stream 
678 morphology in the flint hills of Kansas. Rangeland Ecology and Management 71(6): 783-791 DOI:

679 10.1016/j.rama.2018.06.007.

680

681 Haddeland I, Heinke J, Biemans H, Eisner S. Flörke M, Hanasaki N, Konzmannb M, Ludwigd F, 682 Masakif Y, Scheweb J, Stackeg T, Tesslerh ZD, Wadai Y, Wisser D. 2014. Global water resources 683 affected by human interventions and climate change. Proceedings of the National Academy of 684 Sciences 111(9): 3251-3256 DOI: 10.1073/pnas.1222475110.

685

686 Hauer FR, Resh VH. 1996. Benthic Macroinvertebrates. In: Hauer FR, Lamberti GA, editors. 687 Methods in Stream Ecology. San Diego: Academic Press. p. 339-65.

688

689

Hepp LU, Milesi SV, Biasi C, Restello RM. 2010. Effects of agricultural and urban impacts on 690 macroinvertebrates assemblages in streams (Rio Grande do Sul, Brazil). Zoologia 27(1): 106-113

691 DOI: $10.1590 /$ S1984-46702010000100016.

692

693 Hsieh TC, Ma KH, Chao A. 2015. Interpolation and extrapolation for species diversity (Version 694 2.0.5) [Package for R] Available at http://chao.stat.nthu.edu.tw/blog/software-download/ 695 (accessed 9 September 2016).

696

697 IDEAM. 2015. Precipitaciones anuales en Colombia. Available at 698 http://www.ideam.gov.co/web/atencion-y-participacion-ciudadana/tramites-servicios 699 (accessed 18 May 2016). 
701 Jacobsen D, Marín R. 2008. Bolivian Altiplano streams with low richness of macroinvertebrates

702 and large diel fluctuations in temperature and dissolved oxygen. Aquatic Ecology 42(4): 643-656

703 DOI: 10.1007/s10452-007-9127-x.

704

705 Jost L, 2006. Entropy and diversity. Oikos 113: 363-375 DOI: 10.1111/j.2006.0030-

706 1299.14714.x.

707

708 Kakouei K, Kiesel J, Domisch S, Irving KS, Jähnig SC, Kail J. 2018. Projected effects of Climate-

709 change-induced flow alterations on stream macroinvertebrate abundances. Ecology and Evolution

710 8: 3393-3409 DOI 10.1002/ece3.3907.

711

712 Ladrera R, Belmar O, Tomás R, Prat N, Cañedo-Argüelles M. 2019. Agricultural impacts on

713 streams near Nitrate Vulnerable Zones: A case study in the Ebro basin, Northern Spain. PLoS ONE

714 14(11): e0218582 DOI:10.1371/journal.pone.0218582.

715

716 Larson DM, Dodds WK, Veach AM. 2019. Removal of Woody Riparian Vegetation Substantially

717 Altered a Stream Ecosystem in an Otherwise Undisturbed Grassland Watershed. Ecosystems 22:

718 64-76 DOI: 10.1007/s10021-018-0252-2.

719

720 Lenat DR. 1984. Agriculture and stream water quality: A biological evaluation of erosion control

721 practices. Environmental Management 8(4): 333-343 DOI: 10.1007/BF01868032.

722

723 Lenat DR, Crawford JK. 1994. Effects of land use on water quality and aquatic biota of three North 
724 Carolina Piedmont streams. Hydrobiologia 294(3): 185-199 DOI: 10.1007/BF0002129.

725

726 Llano CA, Bartlett CR, Guevara G. 2016. First Record of the Subfamily Asiracinae and Copicerus

727 irroratus (Hemiptera: Auchenorrhyncha: Delphacidae) in Colombia. Florida Entomologist 99(1):

728 120-122 DOI: 10.1653/024.099.0123.

729

730 Longo MS, Hilldier ZG, Cástor GG, Ramírez J. 2010. Dinámica de la comunidad de

731 macroinvertebrados en la quebrada Potrerillos (Colombia): Respuesta a los cambios estacionales

732 de caudal. Limnetica 29(2): 195-210 DOI: 10.23818/limn.29.16.

733

734 Lucia FD, Costa M, Moraes EML, Telmer, K. 2017. Effects of small-scale gold mining tailings on 735 the underwater light field in the Tapajós river basin, Brazilian amazon. Remote Sensing 9(8) DOI: $736 \quad 10.3390 /$ rs 9080861.

737

738 Malaj E, von der Ohe PC, Grote M, Kühne R, Mondy CP, Usseglio-Polatera P, Brack W, Schäfer,

739 RB. 2014. Organic chemicals jeopardize the health of freshwater ecosystems on the continental 740 scale. Proceedings of the National Academy of Sciences 111(26): 9549-9554 DOI: 741 10.1073/pnas.1321082111.

742

743 Mesa LM. 2010. Effect of spates and land use on macroinvertebrate community in Neotropical 744 Andean streams. Hydrobiologia 641(1): 85-95 DOI: 10.1007/s10750-009-0059-4.

745

746 Meza-S AM, Rubio-M J, G-Dias L, Walteros JM. 2012. Calidad de Agua y Composición de 
747 Macroinvertebrados Acuáticos en la Subcuenca Alta del Río Chinchiná. Caldasia 34(2): 443-456

748 DOI: 10.15446/caldasia.

749

750 Merritt RW, Cummins KW. 1996 An Introduction to the Aquatic Insects of North America. 2 ed.

751 Iowa: Kendall /Hunt Publishing.

752

753 Milner, AM, Piorkowski, RJ. 2004. Macroinvertebrate assemblages in streams of interior alaska

754 following alluvial gold mining. River Research and Applications, 20(6): 719-731.

755 DOI:10.1002/rra.786

756

757 Minshall GW, Robinson CT. 1998. Macroinvertebrate community structure in relation to measures

758 of lotic habitat heterogeneity, Archiv fur Hydrobiologie 141: 129-151 DOI: 10.1127/archiv-

759 hydrobiol/141/1998/129.

760

761 Miserendino ML, Masi CI. 2010. The effects of land use on environmental features and functional

762 organization of macroinvertebrate communities in Patagonian low order streams. Ecological

763 Indicators 10(2): 311-319 DOI: 10.1016/j.ecolind.2009.06.008.

764

765 Moreno CE, Barragán F, Pineda E, Pavón NP. 2011. Reanálisis de la diversidad alfa: Alternativas

766 para interpretar y comparar información sobre comunidades ecológicas. Revista Mexicana de

767 Biodiversidad 82(4): 1249-1261.

768

769 Murtinho F, Tague C, Bievre B, Eakin H, Lopez-Carr D. 2013. Water Scarcity in the Andes: A 
770 comparison of local perceptions and observed climate, land use and socioeconomic changes.

771 Human Ecology 41(5): 667-681 DOI: 10.1007/s10745-013-9590-z.

772

773 Mwangi HM, Lariu P, Julich S, Patil SD, McDonald MA, Feger K. 2018. Characterizing the

774 intensity and dynamics of land-use change in the Mara river basin, east Africa. Forests 9(1): 8

775 DOI: $10.3390 / \mathrm{f} 9010008$.

776

777 Neter J, Wasserman W, Kutner MH. 1990. Applied statistical models. Richard D. Irwin, Inc., Burr 778 Ridge, IL.

779

780 Niemi R, Niemi J., 1991. Bacterial pollution of waters in pristine and agricultural lands. Journal 781 of Environmental Quality 20: 620-627 DOI: 10.2134/jeq1991.00472425002000030019x.

782

783 Ordóñez MV. 2011. Influencia del uso de suelo y la cobertura vegetal natural en la integridad

784 ecológica de los ríos altoandinos al noreste del Ecuador. Thesis, Universidad San Francisco de 785 Quito.

786

787 Park YS. 2016. Aquatic ecosystem assessment and management. Annales de Limnologie 788 International Journal of Limnology 52: 61-63 DOI: 10.1051/limn/2016008.

789

790 Pond G, Passmore M, Pointon N, Felbinger J, Walker C, Krock K.G, Fulton J, Nash W. 2014.

791 Long-Term Impacts on Macroinvertebrates Downstream of Reclaimed Mountaintop Mining

792 Valley Fills in Central Appalachia. Environmental Management 54(4): 919-933 DOI: 
793

794

795

796

797

798

799

800

801

802

803

804

805

806

807

808

809

810

811

812 Reid AJ, Carlson AK, Hanna DEL, Olden JD, Ormerod SJ, Cooke SJ. 2019. Conservation

813 Challenges to Freshwater Ecosystems. In: Reference Module in Earth Systems and Environmental

814 Sciences. Elsevier. DOI: 10.1016/B978-0-12-409548-9.11937-2.

10.1007/s00267-014-0319-6.

Prat N, Ríos B, Acosta R, Rieradevall M. 2009. Los macroinvertebrados como indicadores de calidad de las aguas. In: Domínguez E, Fernández HR, eds. Macroinvertebrados bentónicos sudamericanos: Sistemática y biología. Tucumán: Fundación Miguel Lillo.

Quinn G, Keough M. 2002. Experimental Design and Data Analysis for Biologists. New York: Cambridge University Press.

Rabeni CF, Doisy KE, Zweig LD. Stream invertebrate community functional responses to deposited sediment. Aquat Sci. 2005; 67(4):395-402.

R Core Team 2015. R: A language and environment for statistical computing. R Foundation for Statistical Computing, Vienna, Austria. URL http://www.R-project.org/.

Ramírez YP, Giraldo LP, Zúñiga MDC, Ramos BC, Chará J. 2018. Influencia de la ganadería en los macroinvertebrados acuáticos en microcuencas de los Andes centrales de Colombia. Revista de Biología Tropical 66(3): 1244-1257 DOI: 10.15517/RBT.V66I3.30316.

815 
816 Rivera R, 2004. Estructura y composición de la comunidad de macroinvertebrados bentónicos en

817 ríos de páramo y zonas boscosas, en los Andes Venezolanos. Thesis. Universidad de Los Andes.

818

819 Rodríguez-Barrios J, Ospina-Torres R, Gutiérrez J, Ovalle E. 2007. Densidad y biomasa de 820 macroinvertebrados acuáticos derivantes en una quebrada tropical de montaña. Bogotá, Colombia. 821 Caldasia 29(2): 397-412 DOI: 10.15446/caldasia.

822

823 Roldán-Pérez G. 2016. Los macroinvertebrados como bioindicadores de la calidad del agua: cuatro 824 décadas de desarrollo en Colombia y Latinoamérica. Revista de la Academia Colombiana de 825 Ciencias Exactas, Físicas y Naturales 40(155): 254-274 DOI: 10.18257/raccefyn.335.

826

827 Roldán G, Ramírez JJ. 2008. Fundamentos de Limnología Neotropical. 2ed. Medellín: 828 Universidad de Antioquia-ACCEFYN-Universidad Católica de Oriente.

829

830 Roldán G. 2003. Bioindicación de la calidad de agua en Colombia. Uso del método BMWP/Col.

831 Medellín: Editorial Universidad de Antioquia.

832

833 Roldán G. 1996. Guía para el estudio de los macroinvertebrados acuáticos del Departamento de 834 Antioquia, Pama Editores Ltda. Bogotá, Colombia. 217 pp.

835 Sánchez F. 2004. Aforo con molinete. Salamanca: Universidad de Salamanca.

836

837 Sganga JV, Fontanarrosa MS. 2006. Contribution to the knowledge of the preimaginal stages of 838 the genus Smicridea McLachlan in South America (Trichoptera: Hydropsychidae: Smicrideinae). 
839 Zootaxa 1258: 1-15 DOI: 10.5281/zenodo.173122.

840

841 Sganga JV, Angrisano EB. 2005. El género Smicridea (Trichoptera: Hydropsychidae:

842 Smicrideinae) en el Uruguay. Revista de la Sociedad Entomológica Argentina, 64: 131-139.

843

844 Smith RF, Lamp WO. 2008. Comparison of insect communities between adjacent headwater and 845 main-stem streams in urban and rural watersheds. Journal of North American Benthological 846 Society 27(1): 161-175 DOI: 10.1899/07-071.1.

847

848 Tamaris-Turizo C, Rodríguez-Barrios J, Ospina-Torres R. 2013. Deriva de macroinvertebrados

849 acuáticos a lo largo del Río Gaira, vertiente noroccidental de la Sierra Nevada de Santa Marta, 850 Colombia. Caldasia 35(1): 149-163 DOI: 10.15446/caldasia.

851

852 Terneus E, Hernández K, Racines MJ. 2012. Evaluación ecológica del río Lliquino a través de 853 macroinvertebrados acuáticos, Pastaza-Ecuador. Revista de Ciencias 16: 31-45 DOI: $854 \quad 10.25100 /$ rc.v16i0.501.

855

856 Tolonen KT, Vilmi A, Karjalainen SM, Hellsten S, Sutela T, Heino J. 2017. Ignoring spatial effects 857 results in inadequate models for variation in littoral macroinvertebrate diversity. Oikos 126(6): 858 852-862 DOI:10.5061/dryad.2s4g5.

859

860 Tomanova S, Usseglio-Polatera P. 2007. Patterns of benthic community traits in neotropical 861 streams: relationship to mesoscale spatial variability. Fundamental and Applied Limnology 170: 
862

863

864 Vargas WG. 2002. Guía ilustrada de las plantas de las montañas del Quindío y los Andes 865 Centrales. Manizales: Editorial Universidad de Caldas.

866

867

868

869

870

871

872

873

874

875

876

877

878

879

880

881

882

883

884

243-255 DOI: 10.1127/1863-9135/2007/0170-0243.

Vázquez G, Aké-Castillo JA, Favila ME. 2011. Algal assemblages and their relationship with water quality in tropical Mexican streams with different land uses. Hydrobiologia 667(1): 173189 DOI: $10.1007 / \mathrm{s} 10750-011-0633-4$.

Vásquez Zapata GL. 2009. Calidad de las aguas naturales en relación con el régimen de caudal ambiental. In: Cantera J, Carvajal Y, Castro LM, eds. Caudal Ambiental: Conceptos, Experiencias y Desafios. Cali: Programa Editorial Universidad del Valle.

Villada-Bedoya S, Ospina-Bautista F, Gomes Dias L, Estévez JV. 2017. Diversidad de insectos acuáticos en quebradas impactadas por agricultura y minería, Caldas, Colombia. Revista de Biología Tropical 65 (4): 1635-1659 DOI: 10.15517/rbt.v65i4.26903.

Villada-Bedoya S, Triana-Moreno LA, G.-Dias L. 2017. Grupos funcionales alimentarios de insectos acuáticos en quebradas andinas afectadas por agricultura y minería. Caldasia 39(2): 370387 DOI: 10.15446/caldasia.

Villamarín-Flores, CP. 2008. Estructura y composición de las comunidades de macroinvertebrados acuáticos en ríos altoandinos del Ecuador y Perú. Diseño de un sistema de medida de la calidad 
885 del agua con índices multimétricos. Thesis, Universitat de Barcelona.

886

887 Vimos-Lojano DJ, Martínez-Capel F, Hampel H. 2017. Riparian and microhabitat factors 888 determine the structure of the EPT community in Andean headwater rivers of Ecuador. 889 Ecohydrology 10(8): e1894 DOI: 10.1002/eco.1894.

890

891 Vörösmarty, CJ, McIntyre, PB, Gessner, MO, Dudgeon, D, Prusevich, A, Green, P, Glidden, S, 892 Bunn, SE, Sullivan, CA, Liermann, CR, Davies, PM. 2010. Global threats to human water security 893 and river biodiversity. Nature 467(7315): 555-561 DOI: 10.1038/nature09440.

894

895 Wright, IA, Ryan, MM. 2016. Impact of mining and industrial pollution on stream 896 macroinvertebrates: importance of taxonomic resolution, water geochemistry and EPT indices for 897 impact detection. Hydrobiologia 772:103-115. DOI: 10.1007/s10750-016-2644-7.

898

899 Zapata A, Murgueitio E, Mejía C, Zuluaga AF, Ibrahim M. 2007. Efecto del pago por servicios 900 ambientales en la adopción de sistemas silvopastoriles en paisajes ganaderos de la cuenca media 901 del río La Vieja, Colombia. Agroforestería en las Américas 45: 86-92.

902

903 Zar J.H. 2010. Biostatistical Analysis, Fifth Edition. New Jersey: Prentice Hall.

904

905 Zedková B, Šorfová V, Bojková J, Soldán T, Zahradkova S. 2014. Mayflies (Ephemeroptera) as

906 indicators of environmental changes in the past five decades: A case study from the Morava and

907 Odra River Basins (Czech Republic). Aquatic Conservation Marine and Freshwater Ecosystems. 
908 DOI:10.1002/aqc.2529.

909

910 Zúñiga MC, Cardona W. 2009. Bioindicadores de calidad de agua y caudal ambiental. In: Cantera

911 J, Carvajal Y, Castro LM, eds. Caudal Ambiental: Conceptos, Experiencias y Desafios. Cali:

912 Programa Editorial Universidad del Valle. 


\section{Table 1 (on next page)}

Number of individuals for each recognizable taxonomic unit (RTU) in each sampling zone.

Ref1 = Reference 1; Ref2 = Reference $2 ; \mathrm{CP}=$ Cattle production; Agr = Agriculture; Min = Mining. 


\begin{tabular}{|c|c|c|c|c|c|c|c|}
\hline Order & Family & Genera & Ref1 & Ref2 & $\mathrm{CP}$ & Agr & Min \\
\hline Amphipoda & & Hyalella & 3 & 1 & 138 & 0 & 1 \\
\hline Arhynchobdellida & Hirudinidae & $\mathrm{H} 1$ & 1 & 0 & 0 & 0 & 0 \\
\hline \multirow[t]{12}{*}{ Coleoptera } & Dryopidae & Dr1 & 0 & 2 & 0 & 0 & 0 \\
\hline & Dytiscidae & Dy1 & 0 & 0 & 0 & 1 & 2 \\
\hline & Elmidae & Austrolimnius & 0 & 1 & 0 & 0 & 0 \\
\hline & & Cylloepus & 1 & 16 & 2 & 1 & 3 \\
\hline & & Disersus & 0 & 0 & 0 & 0 & 1 \\
\hline & & Heterelmis & 3 & 13 & 88 & 0 & 2 \\
\hline & & Macrelmis & 2 & 10 & 0 & 0 & 1 \\
\hline & & Neoelmis & 0 & 0 & 0 & 0 & 1 \\
\hline & & Pharceonus & 0 & 0 & 2 & 0 & 0 \\
\hline & Hydrophilidae & Hydrophilus & 0 & 0 & 1 & 0 & 0 \\
\hline & Ptilodactylidae & Anchytarsus & 116 & 82 & 122 & 4 & 49 \\
\hline & Scirtidae & $\mathrm{Sc} 1$ & 106 & 0 & 22 & 0 & 1 \\
\hline Decapoda & Pseudothelphusidae & Strengeriana & 0 & 1 & 0 & 4 & 0 \\
\hline \multirow[t]{19}{*}{ Diptera } & Blephariceridae & Limonicola & 13 & 0 & 2 & 0 & 9 \\
\hline & & Paltostoma & 0 & 0 & 5 & 0 & 0 \\
\hline & Ceratopogonidae & Bezzia & 7 & 0 & 0 & 0 & 3 \\
\hline & Chironomidae- Subfamily Chironominae & Ch1 & 10 & 268 & 41 & 2 & 10 \\
\hline & & Polypedilum & 0 & 0 & 0 & 0 & 3 \\
\hline & & Riethia & 1 & 0 & 0 & 0 & 0 \\
\hline & Chironomidae-Subfamily Tanypodinae & Tany1 & 0 & 53 & 0 & 1 & 1 \\
\hline & Chironomidae-Subfamily Orthocladiinae & Oth1 & 75 & 328 & 31 & 5 & 271 \\
\hline & Chironomidae-Subfamily Podonominae & Podonomus & 10 & 0 & 2 & 0 & 0 \\
\hline & Dixidae & Dix 1 & 0 & 1 & 2 & 0 & 0 \\
\hline & Dolichopodidae & Dol1 & 0 & 2 & 0 & 0 & 1 \\
\hline & Empididae & Em1 & 1 & 5 & 0 & 0 & 19 \\
\hline & Muscidae & Limnophora & 1 & 2 & 1 & 0 & 8 \\
\hline & Simuliidae & Gigantodax & 3 & 0 & 4 & 0 & 2 \\
\hline & & Simulium & 5 & 77 & 82 & 686 & 1 \\
\hline & Tipulidae & Hexatoma & 2 & 4 & 4 & 0 & 5 \\
\hline & & Limonia & 1 & 0 & 0 & 0 & 2 \\
\hline & & Molophilus & 2 & 8 & 0 & 1 & 0 \\
\hline & & Tipula & 21 & 25 & 5 & 13 & 16 \\
\hline \multirow[t]{5}{*}{ Ephemeroptera } & Baetidae & Andesiops & 307 & 46 & 266 & 0 & 163 \\
\hline & & Baetodes & 600 & 458 & 253 & 1 & 630 \\
\hline & & Camelobaetidius & 0 & 2 & 71 & 0 & 1 \\
\hline & & Mayobaetis & 24 & 6 & 7 & 0 & 14 \\
\hline & & Nanomis & 11 & 43 & 0 & 0 & 1 \\
\hline
\end{tabular}


Leptohyphidae

Leptophlebiidae

Hemiptera Veliidae

Lepidoptera Pyralidae

Megaloptera Corydalidae

Odonata

Plecoptera

Trichoptera

Calopterygidae

Libellulidae

Perlidae
Calamoceratidae

Glossosomatidae

Helicopsychidae

Hydrobiosidae

Hydropsychidae

Hydroptilidae

Leptoceridae

Odontoceridae

Philopotamidae

Polycentropodidae

Tricladida Planariidae

Tubificada

Total abundance

\begin{tabular}{lccccc} 
Paracloeodes & 0 & 5 & 0 & 0 & 0 \\
Prebaetodes & 1 & 9 & 4 & 0 & 0 \\
Varipes & 0 & 11 & 0 & 0 & 0 \\
Leptohyphes & 0 & 34 & 18 & 0 & 1 \\
Tricorythodes & 0 & 12 & 0 & 0 & 0 \\
Farrodes & 0 & 1 & 0 & 0 & 0 \\
Thraulodes & 0 & 20 & 0 & 0 & 0 \\
Paravelia & 0 & 0 & 0 & 1 & 0 \\
Rhagovelia & 1 & 32 & 0 & 78 & 0 \\
Cryl1 & 0 & 1 & 0 & 0 & 0 \\
Corydalus & 0 & 3 & 0 & 0 & 0 \\
Calo1 & 0 & 3 & 0 & 22 & 0 \\
Libe1 & 0 & 18 & 1 & 3 & 0 \\
Anacroneuria & 2 & 1 & 13 & 0 & 0 \\
Phylloicus & 1 & 0 & 0 & 0 & 0 \\
Culoptila & 5 & 5 & 27 & 0 & 1 \\
Mortoniella & 0 & 0 & 2 & 0 & 0 \\
Helicopsyche & 1 & 153 & 0 & 0 & 0 \\
Atopsyche & 139 & 50 & 55 & 0 & 87 \\
Leptonema & 0 & 6 & 0 & 0 & 0 \\
Smicridea & 10 & 398 & 62 & 23 & 5 \\
Hydroptila & 0 & 0 & 1 & 0 & 2 \\
Metrichia & 0 & 2 & 0 & 0 & 0 \\
Atanatolica & 0 & 0 & 0 & 0 & 1 \\
Nectopsyche & 4 & 1 & 4 & 0 & 1 \\
Oecetis & 0 & 0 & 0 & 1 & 0 \\
Triplectides & 0 & 1 & 0 & 0 & 0 \\
Marilia & 0 & 6 & 0 & 0 & 0 \\
Chimarra & 0 & 2 & 1 & 19 & 0 \\
Polyplectropus & 1 & 0 & 0 & 0 & 0 \\
Dugesia & 1 & 5 & 24 & 178 & 1 \\
Nai1 & 14 & 0 & 3 & 8 & 6 \\
\hline & 1506 & 2233 & 1366 & 1052 & 1326 \\
\hline
\end{tabular}

1 
Figure 1

Study area and sampling zones located on the western slope of the central cordillera of the Colombian Andes, in the Chinchiná river basin (Caldas, Colombia).
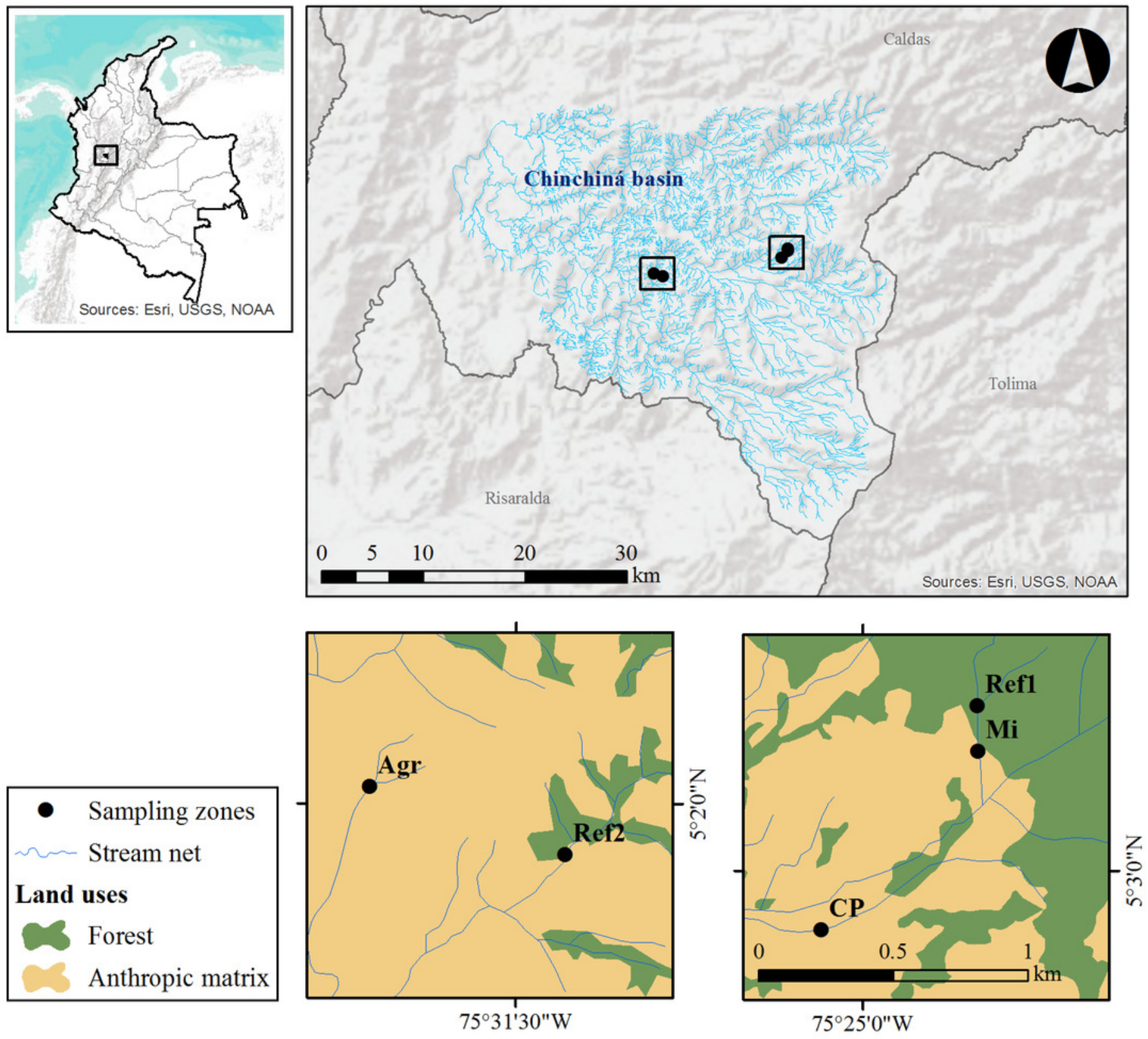


\section{Figure 2}

Comparison of the density and diversity of aquatic macroinvertebrates (AMI) in five sampling zones.

(A) Boxplot showing the median AMI density. (B) Patterns of diversity expressions, richness

$(D)$, typical diversity $\left({ }^{1} D\right)$, and effective number of the most abundant morpho-species $\left({ }^{2} D\right)$.

The vertical line indicates the $\mathrm{Cl} 95 \%$ per ${ }^{9} \mathrm{D}$. No share letters above boxplot indicate the statistical difference between pairs of the sampling zones. Streams: Ref $1=$ Reference 1 , Ref $2=$ Reference $2, \mathrm{CP}=$ Cattle production, $\mathrm{Agr}=$ Agriculture, and $\mathrm{Mi}=$ Mining . 

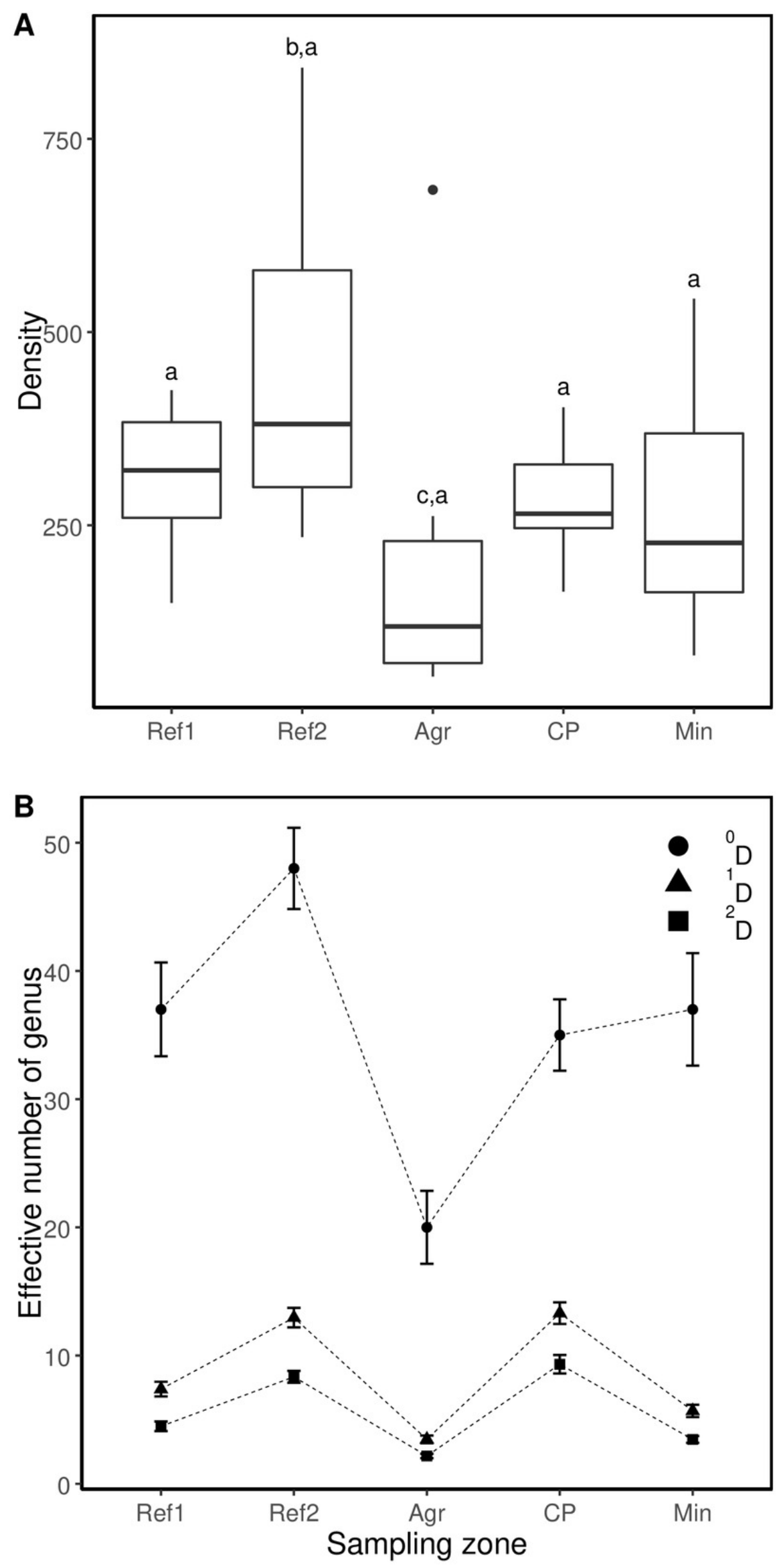

Peer] reviewing PDF | (2019:06:38347:2:0:NEW 25 Jun 2020) 
Figure 3

Rank - Density curve the RTUs of aquatic macroinvertebrates recorded in five sampling zone, Chichiná basin, Colombian Andes.

Ref1 $=$ Reference $1 ;$ Ref2 $=$ Reference $2 ;$ Agr $=$ Agriculture $; \mathrm{CP}=$ Cattle production; $\mathrm{Mi}=$ Mining. Bae $=$ Baetodes; And $=$ Andesiops; Ato $=$ Atopsyche; Anc $=$ Anchytarsus; $\mathrm{Sc} 1=\mathrm{Sc} 1$; Oth1 = Oth1; Smi = Smicridea; Ch1 = Ch1; He = Helicopsyche; $\mathrm{Dg}=$ Dugesia; $\mathrm{Rh}=$ Rhagovelia; Hy = Hyalella; Cam = Camelobaetidius; Cul = Culoptila. Showed the RTUs with density larger $>25$ inds $* m-1$
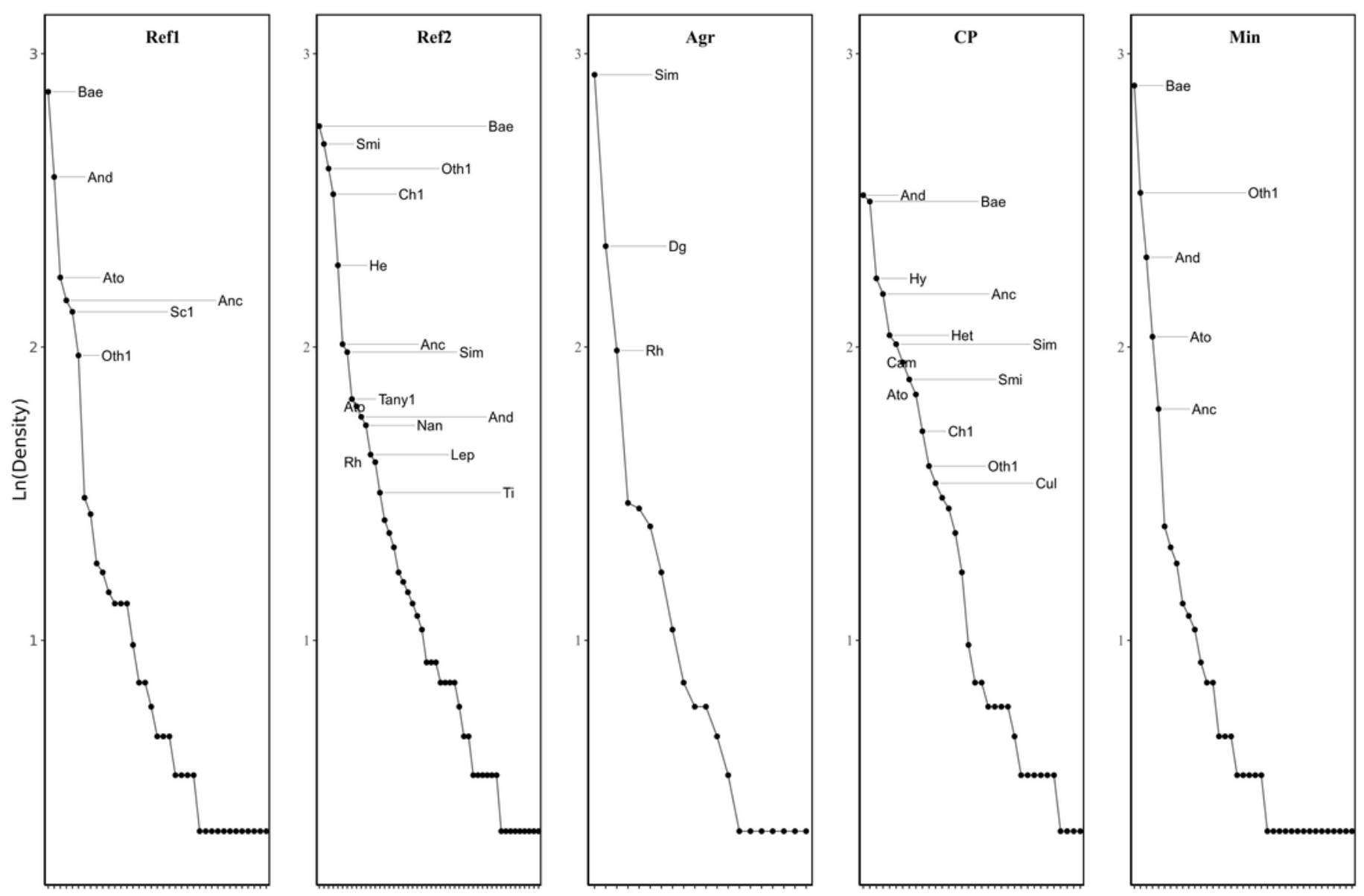
Figure 4

Non-Metric Multidimensional Scaling (NMDS) analysis based on the Bray - Curtis Index considering each sampling event per zone (Stress $=0.13$ ).

The names of AMI RTUs are shown (see Table S2). Streams: Ref $1=$ Reference 1 , Ref $2=$ Reference $2, \mathrm{CP}=$ Cattle production, Agr $=$ Agriculture, and $\mathrm{Mi}=$ Mining .

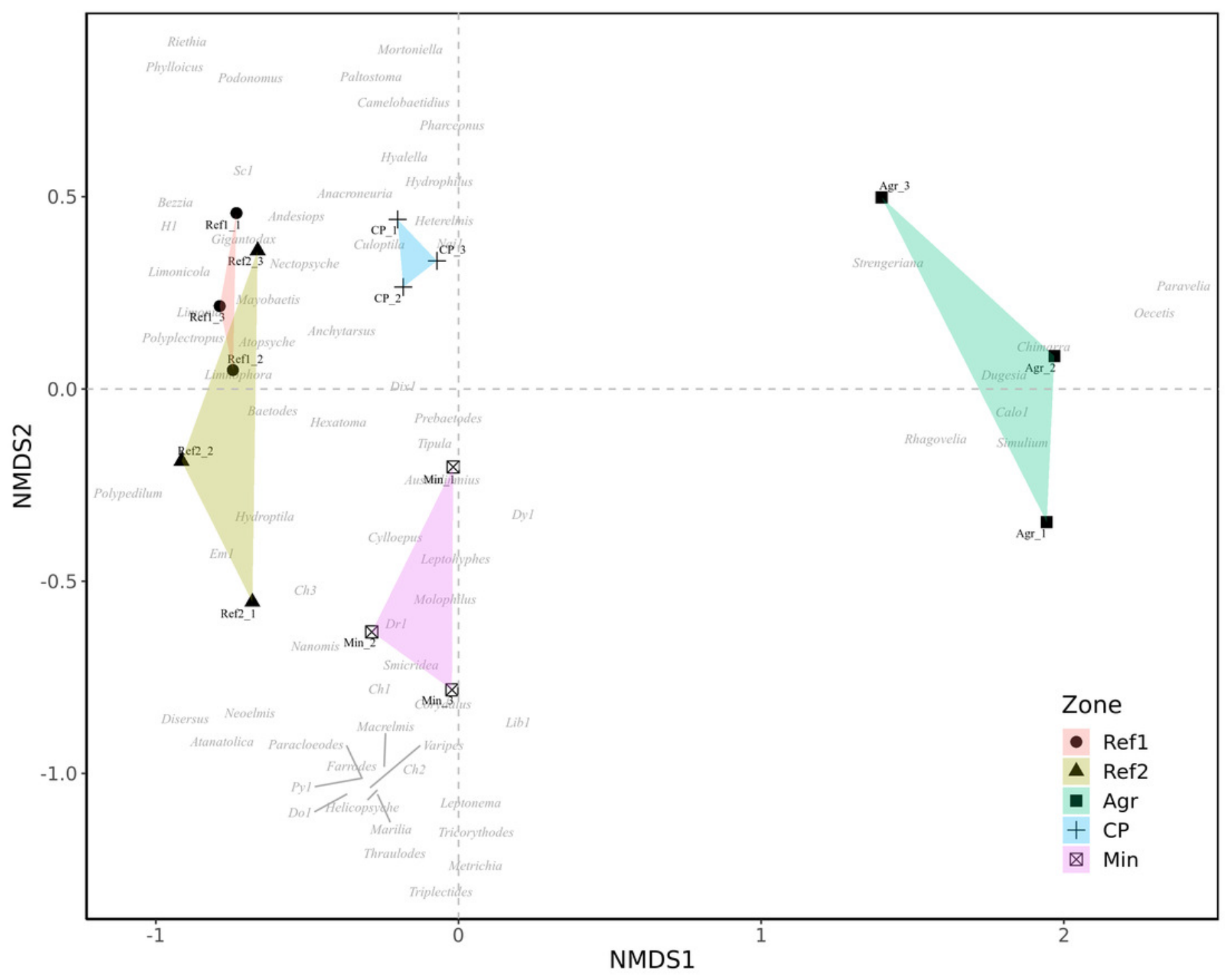


Figure 5

Correspondence Canonical Analysis (CCA) among AMI RTUs composition and eighth hydrological, physicochemical, bacteriological (HPCB) parameters regarding measure events per sampling zone.

The selected HPCB parameters present a VIF $<10$. Streams: Ref $1=$ Reference 1 , Ref $2=$ Reference $2, \mathrm{CP}=$ Cattle production, $\mathrm{Agr}=$ Agriculture, and $\mathrm{Mi}=$ Mining. Mesarure events: 1 $=$ Feb14 + Apr14; 2 = Jul14 + Sept14; $3=$ Nov14 + Nov15.

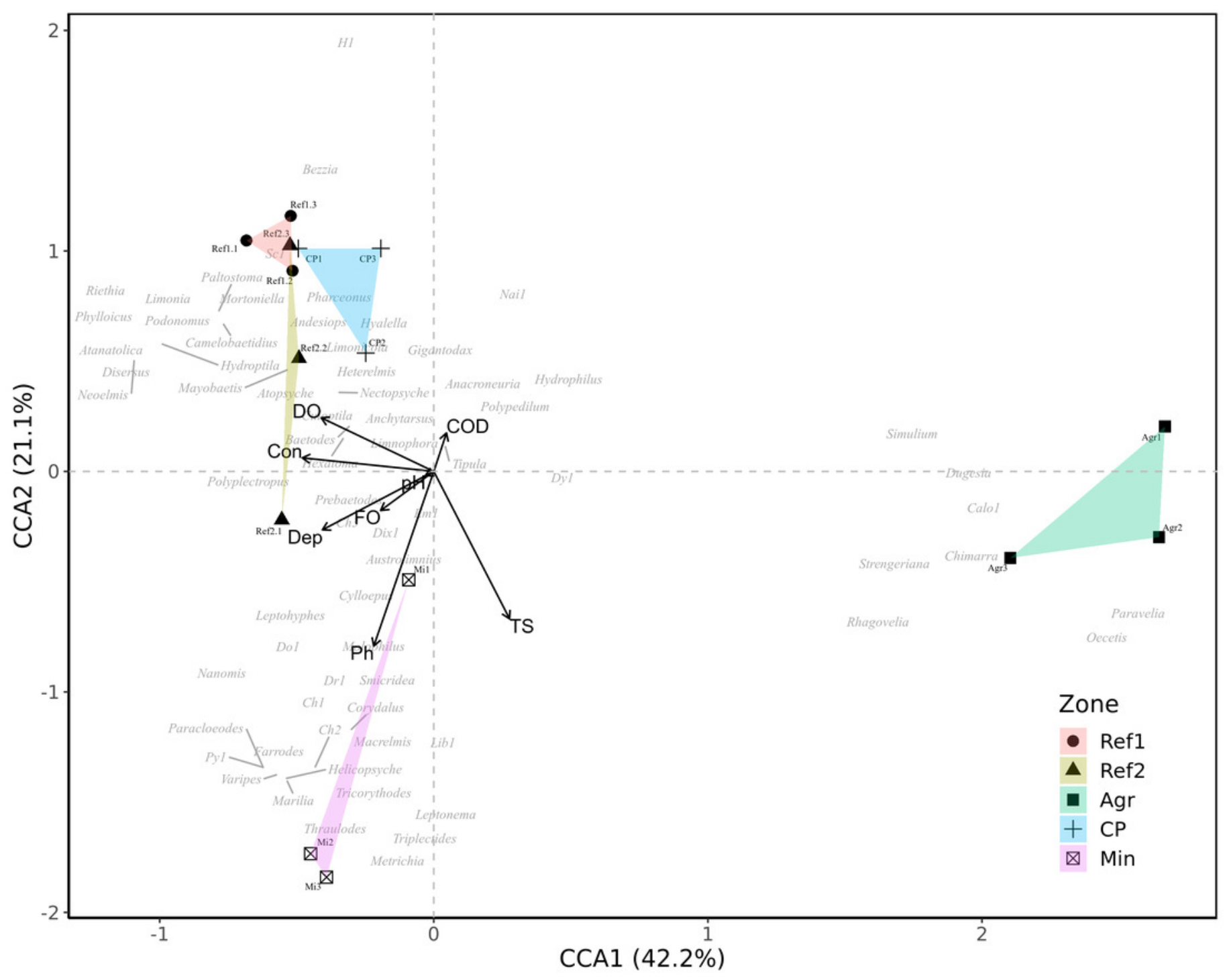

